\title{
NOTES ABROAD.
}

During the past academic year the writer has made a pedagogic trip through Germany, France, and Great Britain. His attention was directed mainly to university courses bearing on psychology and pedagogy, and the aim was to meet men and get ideas. Arriving in Germany at the close of the summer semester only a few days remained of the lectures. These days were spent at Giessen in Hessen, the inopportune deaths of Professors Wolff and Meyer at Boun, and of Prof. Preyer at Wiesbaden having rendered futile the previous stops. The following notes are left in unelaborated form as better suiting the informal nature of the trip and the personal character of the facts.

During the summer semester of 1897 the only course of lectures on child study in the philosophical department of any German University was that on "The Mental Life of the Child " by Prof. Karl Groos at Giessen. Groos's study of play in auimals has been followed by a study of play in children and this subject has led him, in order to familiarize himself with the whole of child life, to gather the material for the course above mentioned. Being unique in Germany, the cuurse was announced with many misgivings as to its success, but it was attended by a considerable audience of interested students. Prof. Groos, who has this year accepted a call to Basel, is a young man (b. $186 \mathrm{I}$ ), hungry for information from abroad and eager to avail himself of new ideas, an enthusiastic worker, and a man of great promise. His second volume on the plays of child ren is now ready for the press.

Prof. Hermann Schiller (b. 1839 ) is a man of wide experience and a uthor of numerous pedagogical writings, loquacious in conversation and reminiscent in lecturing. He is sometimes classed with the Herbartians; but, although adopting a sort of concentration idea and favoring the formal steps, he repudiates the name and belittles their infuence. According to his view, the Herbartians in Germany are a vanishing quantity, their great leaders (Stoy, Frick, Dörpfeld, etc.) dying and leaving too little interest and energy in the younger generation to continue their work. Schiller, in company with Ziehen in Jena, is editing a new series of pedagogical and psychological nonographs and, like Erdmann (formerly in Halle and now in Bonn) has done some experimental work himself, with the result that he "don't think much of it all anyway." The united library of the gymuasium and university seminar is exceptionally large and well supplied with special pamphlets representing the newer ideas and current pieces of work. The able professor of modern languages, Dr. Dorfeld, is librarian, and has charge of the initiation of candidates for secondary schools into their work in French and English.

Arriving at Jena in time for the vacation courses of the Rein School, I had expected to find there the cream of thought and new ideas rising to the surface and ready to skim. But the great percentage of strangers from abroad has turned the lectures into a school for teaching German to foreigners. For this purpose it is excellent, but I found only one course that seemed to have any material in it more recent than ten years old. This work was by Dr. $O$. W. Beyer, who has made a specialty of manual training. He had a room full of books on the subject, pasteboard models, and diagrams, and at the close took his 
class up the Saale valley to Pössneck to examine ove of the best organized school-gardens in Germany. There on a plot of ground prepared in 1895 at a cost of $\$ 750$ and requiring an annual outlay of only $\$ 75$, six hundred pupils have each his or her separate garden patch, and every day between 5 and 6 P. M., they come to weed, water, hoe, train or otherwise attend to and reap what they have sown. The central path in the garden is reserved for the parents who come there to promenade and enjoy the sight as well as encourage their children and help them carry off the armloads of cabbages, potatoes, lettuce, onions, turnips and flowers for home consumption. Besides these separate beds, the garden contains a tree nursery, a frame shed for class use (as the school building is fifteen minutes distant), separate sections for industrial plants, hemps, flax, wheat, corn, rye, etc., for poisonous plants and noxious weeds, for alpine or mountain flora and for swamp plants. As far as possible, plants that grow together in nature are kept together under natural conditions in the garden.

In a new edition of Rein's "Theorie und Praxis," Dr. Beyer has been commissioned to revise the entire curriculum from this new stand point of handwork, bringing everything into organic relation with it and making it the center out of which the other school subjects grow. For these ideas, compare his "Naturwissenschaften in der Erziehungsschule," (Langensalza).

The new building for the Practice School at Jena is completed and the school expected to move in last Easter. In addition to three smaller classrooms, there is one larger classroom for the Probelektionen when all the seminary attend, one large room for the Thuringian School Museum and one for the Seminary Library, beside office and three living rooms for the training teachers, and in the basement, gymnasium, bath and workshop. The building is of brick and sits back from the street a considerable distance and is surrounded by the school garden. It is unique in Germany, all the other universities concerning themselves exclusively with gymnasial pedagogy and therefore utilizing a regular gymnasium as practice school.

Taking a suggestion from Helena Lange, E. A. Fabarius proposes in "Die allgemeine Dienstpficht" to require by law of every normal girl of eighteen years of age three years' service in housework, nursing, sewing, etc., corresponding to the obligatory army service for the meu. Another proposal in "Der freiwillige Dienst in der Wirthschaftlichen Frauen-Hochschule" by Ida von Kortzfleisch plans to give girls of 20 years who have passed through the Höhere Töchterschule a training in woman's work. Both of these proposals merit attention.

Trüper's Institution for abnormal children is ideally situated on Sophienhöhe, overlooking Jena and the valley of the Saale. Each pupil is studied individually and a careful record kept of physical and psychical tests, treatment and reactions. A series of such life histories or "pedagogical cases" (corresponding to the cases of the lawyer or the doctor) is being published in "Kinderfehler" (Langensalza), which seems to be almost the only child study periodical in Germany.

Director Ufer in Altenburg, who, nervous himself, has made careful studies of nervousness in school children, and has recently reissued Sigismund and Tiedemann with notes, seems to be the coming leader of child study work among the German teachers. At the spring meeting of the the Thuringian teachers at Erfurt, he was to propose the formation of a German society for child study. While at Altenburg I heard him give one of the very best lessons on the $7^{\text {th }} \mathrm{Com}$ mandwent, developing the ideas of the family relation, its importance, mutual duties and helpfulness. He treated successfully delicate topics of the home, love, duties of children and their rights in a 
masterly way that was simple, impressive and adapted to children, without being childish. If we could have such lessons in religion in our schools we should gain much.

Prof. Fritz Schultze in Dresden is writing a "Vergleichende Seelenkunde," the fourth volume of which will contain a genetic psychology.

One of my most charming excursions from Jena was with Dr. Lindley to the old homes of Frobel on the border of the Thuringian Forest. We took the steam car to Rudolstadt, famous for its Anchor building blocks that have delighted millions of children. Beside the building blocks, Richter has a chocolate and candy factory, a bathing establishment and a sanitarium, a patent medicine laboratory and warehouse, lives in a palatial castle and owns nearly all the ground on which the city stands. Keilhau is about an hour and a half distant. Most of the old buildings are still standing, although much added to. The school is now converted into a regular Realschule and has lost entirely its original character of experimental school. It is situated in as lovely a valley as exists in Germany. We can understand some of the love of nature that breathes through the pages of "The Education of Man" when we look upon the surroundings in which Fröbel wrote and worked. Fifteen minutes' walk beyoud the school brought us to the top of a ridge from which a magnificent panorama of the whole valley in which Blankenburg lies and the northeastern part of the Thuringian Forest stretched out like a map. In Blankenburg, Frobel's old home is now a bicycle repair shop and the house in whlch he established his first kindergarten is part of a public school, what was the "children's garden," according to Unger's drawing, laid out with separate flower beds, is still a garden but not used by the school. We found a number of old pupils of Fröbel who could tell anecdotes and experiences.

The old university building in Bologna is exceedingly interesting with its historic clinical auphitheater, its court of honor covered with the names of its illustrious former members arranged by nations, and its new halls with memorial tablets to its women professors. In front is a marble statue of Galvani performing his epoch-making experiment on the frog.

Our School for Classical Studies at Athens is engaged on very im. portant excavations on the site of old Corinth that have been so far successful that the site of all of the chief public buildings in the ancient city has been determined, although when the excavations began the only visible remains were a few ruined pillars of an uncertain temple. At Athens the Parthenon is being rescued from what would soon be certain destruction by the weather and by earthquakes. New marble girders are taking the place of the old blocks that had become rotten with age and the loose pieces are being braced with iron.

In Vienna there is nothing new of interest in pedagogy at the university. Prof. Vogt, the president of the Ver. f. w. Päd., is an able logician but aims at nothing more than clearness of exposition of $\mathrm{Zil}$ ler's work. The university is in no sort of sympathetic rapport with the schools and therefore exerts no noticeable influence on them. Ou the other hand, the Austrian teachers look back gratefully to Dittes who was opposed at erery turn by the present professor of pedagogy. Dittes's work is continued by Hannak, whose interest in pedagogy, however, is chiefly bistorical. The Pedagogium is unique in being a continuation school for city teachers in office.

Every student of school hygiene knows of Prof. Leo Burgerstein, but perbaps not many know that he is by profession a geologist, which 
subject be teaches in a Realschule, giving only his spare time to the study of school fatigue, etc. He was the most helpful man I met in Vienua and gave unstintingly of his time and resources, going over his more than 150 correspondents in all parts of Earope and advising what men to see and what places would be worth visiting. His pioneer work on school fatigue was carried on in the face of great discouragements and utter lack of cordiality on the part of the school authorities. The data obtained were worked over to a much greater extent than their reliability justified, in ordcr, as Burgerstein eaid, to demonstrate what could be done if data were taken in greater quantity and under more cordial conditions. Burgerstein was busy on a report on Wohlfahrtseinrichtungen to be presented at the Emperor's jubilee in May of this year. After this he intends to return to his previous investigation into school fatigue.

At Breslau, Ebbinghaus was lecturing on experimental psychology and pedagogy. He attracts students by his own personality and vivacious, lucid style, rather than by any material facilities. For, there was no laboratory to show and no research was in progress, except the one being conducted on school fatigue by a special commission of which Ebbinghans is the most prominent member. In fact, he says the German students that come to him do not want to become psychologists but wish only a survey of the field, 80 he aims to meet this want, giving up original research since married life makes impossible that regularity and uniformity of life necesaary for a reliable experimental self-study of mental work. He gives up all his spare time to his editorial labors and writing his new book. He wishes some one would take his work on memory more in earuest and carry it forward, as he believes it is entirely possible to do 80 .

Dr. Stern, Prof. Ebbinghaus's assistant, is promising young private docent of whom I heard good report.

Genial, sociable almost to a fault, and so well known that even the dogs wag their tails and prick up their ears as he pasees, Hermann Cohn, better known as Augen-Cohn, has to stop when going along the street, every five or ten minutes, for personal exchange of friendly words with his thousands of acquaintances. He has been a specialist in eye discases for over thirty years, introducing many reforms in manipulations and improvements in operations. He has lectured without pay for a quarter of a century at the university.

Leipzig undoubtedly has now as fine university buildings as there are in the world. The money has been well spent, without ertravagance, but everything of real value has been secured of the best qnality. The electrical lighting is excellently arranged. The light thrown by reflectors placed under the large arc lights is a second time reflected from the white ceiling and dispersed evenly over the entire room. It is easier on the eyes than daylight, because of its evenness.

Prof. Wundt, greater now as philosopher than as psychologist even, appears at his best at present perhape as a lecturer. His masterly presentation of Greek philosophy and race psychology last winter was heard by a crowded auditorium of over four hundred. The new rooms of the psychological laboratory, fourteen in number, arranged according to his plans, are by far the most extensive and complete in Germany, and contain unany historic pieces of apparatus as well as some very new and costly ones. The new peychology bas many opponents still in Germany. Men such as Paulsen in Berlin, Erdmann in Bonn, and Fischer in Heidelberg minimize its advences or, like Heinze in Leipzig, believe that Wundt will yet live to see a great reaction, and that this revulsion in confidence in the new psychology is now well begun. To 
all of these sceptical misgivings Wundt smiles placidly, full of confideuce and clear as to the grounds of his faith.

Flechsig is an extremely interestiug man to tneet, full of his new discovery of "Denkorgane," and ready to talk to any one who is interested and appreciative. The whole matter is in a state of flux in Flechsig's own mind. One time he will tell you be is sure of 30 centers positively demonstrable, and a few weeks later he is just as sure of 40 . This unsettled condition of his ideas is retarding the issue of his new book, for which the plates alone are said to cost fifty thousand marks.

Volkelt seems very bright and keen, perhaps a little narrow, but an excellent man to work with. He was conducting a good seminary in Herbart's Allgemeine Pädagogik, with thorough elucidation and lively discussion.

Heinze speaks indistinctly and fails to look you in the eye, but is a charming man to meet and has written an extremely serviceable continuation of Ueberweg's History of Philosophy, giving an account of current philosophers.

Poor old Prof. Strumpel still lectures on the Criteria of Truth. It is a pathetic picture to see the feeble old man come in leaning on the arm of his famulus and sit down to continue his course, "if God permits him to finish."

Prof. Marcs had an excellent seminary in historical method. The aim was to train in the weighing of evidence, siftiug truth from error and dealing directly with the original sources. The period treated was the March days in 1848 in Berlin, when the king's vacillation was encouraging lawlessness.

The professors of pedagogy in Germany, with perhaps the exception of Rein, seem to have no interest in the study of educational problems, and nowhere did I find them doing anything themselves along the newer lines. Several, while lamenting it, admitted frankly that ped. agngy was a dead subject at the universities, and that they looked to America for new inspiration.

Halle has a splendid set of medical buildings, and makes a great showing with such men as Hitzig, Roux, and Bernstein.

The most American professor in Germany is perhaps Conrad, who has exexcised the greatest influence in the education of many of our leading economists. He conducts a seminary, in which the interest is intense and maintained, the discussion always lively and earnest. These results, are due solely to his pedagogic tact.

The Frankeschen Stiftungen are always a mine of pedagogic wisdon, if one has time enough to stay for two or three weeks. In less time one canuot form any adequate conception of the schools. Frick's Seminarium Præceptorum is continued under Director Fries.

Berlin is badly off for a satisfactory university.building, avd after being accustomed to the commodious and hygienic I,eipzig palaces, one is painfully impressed with the poor lighting and barl veutilation at Berlin.

Stumpf is a wonderful man in his field and be kecps pretty close to it, thoroughly German in his specialistic ideas, and with no interest for any thing else. His assistant, Dr. Schumann, is an able, industrious and obliging worker, who is sure to rise to eminence in his subject. The laboratory occupies four rooms, dark and cramped for space, but containing several pieces of apparatus of much interest and adapted to the special investigations under way on sound. Some new work on the tendeucy to group similar objects into units and the influence of this on the formation of judgmeuts of differences is in progress.

The new professor of pedagogy at Berlin was cold, his lectures were 
delivered in diplomatic language, containing no new ideas, and he himself was in no sort of rapport with his class.

Paulsen was disappointing. One expects a good deal of such a tremendous physique and that grand, broad head, and he has done great things in his published works; but his lectures on pedagogy, while the best in Germany at present, are just about the same as be was delivering eight or ten years ago. No wonder the professor loses bis enthusiasm.

Max Dessoir is a charming personality, a "ladies' lecturer," polished, graceful, always prepared without notes and always with fresh material. He puts one at one's ease immediately, and you feel as if you must have known him before. He practices what he preaches. He was lecturing on literature and spoke of the ideal sort of conversation between those who meet on terms of perfect equality, as in the French salons of last century. Helmholtz's evenings in Berlin were the last thing of that sort in Germany. Our modern use of titles and even the sycophant "Sie" in address makes such perfect freedom and feeling of equality impossible. He takes 5-6 hrs. in preparation for every hour of lecture, and never attemps to carry more than seven hours of lectures per week. When he has worked a subject up in lecture form satisfactorily he publishes it, and then does not lecture on it again for some years, until it has sprouted new ideas. In this way he keeps fresh and growing.

Simmel is another of the young docents in Berlin who are doing some original thinking and attracting students by their real merit.

Baginsky is getting out an entirely new edition of his School $H y$ giene. He "just lectures for his own amusement," and does not think as much of other people's work as of that done by himself.

Lassar and Behrends had advertised public lectures on syphilis for students of all the faculties, and one of the courses was held in the great auditorium, capable of seating nearly 500 . But both lectures were interspersed with coarse, indecent jokes, and pandered to a morbid curiosity, without one word of awakeuing to higher views or nobler motives. They were sensational, but in no way pedagogical or inspiring.

Dilthey gives a clear, good note book, as the German student says, and pounds it in with a ridiculously monotonous left-banded gesture. Indeed the automatisms of the professors are extremely interesting. Paulsen carries a pencil, which he places carefully on the desk when he begins to speak. In about five minutes or less he picks it up as he would a new thought and plays awhile with it in his hands, and then as carefully places it on the desk again just as he finishes one topic and is about to go over to another. Wundt makes only one gesture, an ambidextral outward movement with his hands as he leans on his elbows. Eucken looks at the ceiling. Richet makes a continuous double-handed gesture of depreciation, as wuch as to sey: "This is all very trifing and trite, I know." Izoulet rubs his hands at the beginning of his lecture as if getting ready to fight, and then holds up his right hand as if he bad the thought between his thumb and middle finger. Giard puts his hands behind his back and promenades up and down the platform, looking at the floor. Raymond in Charcot's old clinic in the Salpetriere holds the idea between the thumb and middle finger of his right hand, and then springs up and down in his chair, as if on horseback, going higher and faster in proportion to the intensity of the idea, and sometimes getting one foot in to the seat of his chair and actually sitting on it as on a spring.

Gutzmann (Berlin) is a specialist of international reputation. In his recent pamphlet on early reading he has brought out the same 
idea that Dr. Hartwell so graphically portrays in his famous report of I894; viz., that stuttering increases 3 to 4 fold in the $7^{\text {th }}$ year, oxing to faulty methods in school. The phonic methods of Graser and Krug are commended with slight modifications. He has been making some experiments with telephone sounds, and he finds that transmitted nonsense syliables cannot be distinguished. This shows what important apperceptive helps are the context and the orertones. Any one who has had to talk with a foreigner through a telephone will be able to confirm this from his own experience.

Inspector Piper (Dalldorf, near Berlin) teaches feeble-minded children to speak correctly by making them conscious of the right position of the vocal organs, and developing from this a sort of visible speech, simpler than Dr. Bell's. He has recently issued a child's primer on this plan.

E. Pappenbeim is the very pleasant and able head of the Kindergarten Society of Berlin. This society very wisely opposes the transfer of the kindergarten to the school authorities on the ground that its methods are not ready yet to be stereotyped, but must have freedom for development, and that is not possible after it passes into governmental control. Child study, Pappenheim says, is the method of developing the kindergarten, but "always let us insist that Fröbel shall be understood before his ideas are modified or developed."

The Hamburg Drawing Teachers' Association is the center just now of the greatest activity in the reform of drawing methods in Germany. They are going at it from the standpoint of child study, and last spring organized an extensive international exhibition of.children's drawings in the Kunst-Halle of Hamburg. They have been collecting literature, and have issued several pamphlets, among them one on the developing of artistic taste through the study of pictures in school.

Although Kuno Fischer refuses to have a psychologist at Heidelberg, and although Kraepelin himself declares he is no psychologist, but an alienist, it still remains the fact that Heidelberg is one of the best places in Germany to study psychology. Kraepelin's chief labors during the last ten years have been directed to the problem of mental work, its conditions, individual differences, the influences of drugs on mental activity, and the hygiene of work. This problem of mental work is the essential question in pedagogical psychology, and hence, tco, Heidelberg is the best place to study experimental pedagogical psychology. There are two able assistante in the laboratory, one of whom, Dr. Aschaffenburg, has already done notable work in exbaustion, the other, Dr. Michelson, has made new investigations on sleep. The laboratory includes only three rooms, but contains many new and ingenious pieces of apparatus. Dr. Nissl's work in histology promises to be revolutionary of the neuron theory.

Bernheim's pamphlet on "Der Universitätsunterricht und die Frfordernisse der Gegenwart" (Berlin, 1898), touches an important subject greatly needing discussion. The reform proposed is, in brief, as follows: (I) The Private Courses of lectures (privatim and privatissime) of six hours or more per week should be abolished, and in their place should be substituted (2) Short Courses of orientation (one to two hours , much covdensed, giving chief view points only, with reference to more important literature; (3) Practical Exercises from first semester onward ( $t$ wo to four or more hours per week), to initiate students into general scientific and specialist observation and thinking, and accustom them to clear formulation of their thoughts orally and in writing. The present existing seminars will not be changed in their arrangements, but will be given a firmer organization and strengthened rela- 
tions to one another, and to the whole of university teaching. They are all to be arranged in two grades, for beginners (Proseminar), and for advanced students (Seminar), and all will acquire greater importance in proportion as they are pushed into the foreground of university work; (4) combination of systematic presentation with practical exercises, $e \cdot g$, in archaology and art, history, natural science and medicine by demonstrations. exercises, excursions, etc., in connection with the lecture course. Similar arrangement is possible in the human. ities. In the Proseminars the students (a) would learn to consult libraries. "The lack of knowledge of books is really a shameful fact in our academic life to-day." (b) They would come at once into contact with the professors, and would feel the stimulus, and the teacher could the more easily get into rapport with the hearer and advise him, help him to supplement his knowledge where he is ignorant, and test how far his own method of work is pedagogical. (c) They would be much better prepared to enter the seminars, which would thus be raised in grade. Single professors cannot start the reform in practice. It must first be discussed generally, and then introduced simultaneously everywhere: Examination ordinances must require, for doctor's degree and for state examination, the production of work done in each year of university residence, and signed by docents and dated. A year and a half to two years of Proseminar exercises should be required, and one year to a year and a half of original investigation in the Seminar.

Alfred Binet lives in a modest house a short distance out from Paris, and bere he works undisturbed, free from any obligation to lecture or examine students, and under no limitations as to work. For, although director of the psychological laboratory of the Sorbonne, he is relieved of all care by his two assistants, and devotes himself entirely to his research work and to publication. It is very different from the work in Germany ; for Binet has no seminar, and does not expect to train psychologists. Rather, he has gathered about him a half dozen or so young men who work with him, as if in partnership. The most gifted and promivent of these younger men is Victor Henri, who in every way is Binet's right-hand man. A Frenchman bv birth, Heuri has spent much of his time in Russia, where he married, and in Germany where he studied with Muiller at Göttingen.

Binet \& Company are working up individual psychology, and have developed about 70 tests applicable to pupils in public schools. Of these about half are "quite satisfactory." They go every fortnight to two normal schools out from Paris and put the students through the tests. They have been doing this for about two years, and propose to work up the results with reference to seasonal changes and weather influence. Nearly all the tests they commonly ase aim to reveal the relation between physiological und psychical functions. A mong the usual tests are the following: (1) rank in class, (2) memory for numbers, (3) circumference of chest, (4) height, (5) weight, (6) running time, (7) reaction timé (simple), (8) reaction time with choice, (9) counting "petits points," (10) diameter of head, (II) fatigue curve by ergograph, (12) pulse, (13) breathing. They aim also to test the imagination by such questions as these: (a) The teacher takes a square piece of paper and folds it diagonally, and folds the resulting triangle again. Then with the scissors a piece is cut out of the last triangle. Query: what will be the resulting shape when unfolded ? (b) A strip of paper is twisted once and the ends pasted together. Then with the scissors the strip is cut around on the middle line. Query: what will be the resulting form? If the resulting ring is similarly cut along the middle line, what figure will 
result ? The pupils are also asked to describe simple objects distributed to them, $e . g$, a pen, or a double sou. Lately the camera has been used to photograph automatisms. It is proposed to publish the results of these studies in a new series under the title Bibliothèque de Pedagogie et de Psychologie. The first volume of this series is out: La Fatigue Intellectuelle. The second is announced on L'Education de la Mémoire.

Theodule Ribot, although associated with the Binet school, is an independent worker, and undoubtedly the most reliable and ablest psychologist in France. There is considerable jealousy between the two parties, and neither thinks very highly of the other's way of working.

Ribot was born in Brittany in 1839 . He is short, frail looking, with little, nervous twitches of the head and eyes. In answer to the question, why don't the French do more work in psychology in the university ? Ribot replied that the work in the psychological laboratory did not count toward the degree, nor was it included in any examination for the degree. Secondly, the French have not the perseverance and patience necessary to accurate introspection. Ribot says that, at the College de France, he must count on the usual point of view of his audience being that of logic and intellect. They do not comprehend the emotional life, and would not understand him if, as he would like, he should address them from the standpoint of the emotions. He has, however, great hopes of the advance of psychology by the study of the sentiments and feelings. The most promising field in psychology at present is that of attention. There are many fundamental questions raised by Wundt's position, by Münsterberg, by James, and others, but much can also be solved by experiment.

Jules Soury is also an independent worker, lecturing on psychology in the F.cole des Hautes Etudes. Perez, who used to write so tediously on child study, has become a melencholiac in an asylum outside of Paris. Buisson is doing very good normal school work in pedagogy at the Sorbonne, reading educational classics, and having essays written on them.

Having opportunity to accompany one of the medical inspectors on his visit to the schools, I saw something of the surface routine. Dr. Mangenot has drafted a project of a law requiring daily visits and individual examination with separate individual bulletius for each pupil. All the pupils are to be weighed and measured twice a year. These data are to furnish the basis for indicating to the teachers (I) how to seat the pupils, (2) which to relieve of home-work or gymnastics, (3) which need medical attention outside, (4) which need "preventive medication" ( $i$.e., supplement to home diet, $e . g .$, cod-liver oil, etc.), (5) which pupils should join the "colonies scolaires."

Izoulet was lecturing on Rousseau to crowded audiences of students, society women, professors and men of affairs in the College de France. There were many demonstrations of approval and disapproval. "Under the old order of things, men were chosen by aristocracy of birth; under the new order on the basis of a diploma by examination. But only the mediocre pass an examination. Original thought does not help one to pass. We are training for mediocrity."

In the art academies of Paris all students, beginners a well as veterans, drawers in charcoal as well as painters in oil, and modellers in clay, work from the human figure. Nothing else is so interesting. so adapted to all stages of progress, so readily criticised and mistakes so clearly felt and appreciated. On the Saturday visit of the professor, the weekly sketches are criticised and marked. Among these are often to be fond excellent pieces of work, with much simplicity and depth of feeling. 
An exceedingly interesting and valuable work is being done by $\mathrm{Dr}$. Edgar Berillon in his Institute in Paris, where he cures common faults of children, e. $g$., onychophagia, onanism, lying, laziness, fear, etc., by the method of suggestion. Every teacher must be struck by the proposition laid down by Bérillon that educability is measured by suggestibility. What an unused power in the school room, where the ideal so often is to reason and to compel by authority. ( $C f$. article on "The method of suggestion in the cure of faults" in the May number of the North Western Monthly.)

Sir Joshua and Lady Fitch were charming in their hospitality, and eager to show their warm interest in everything relating to Americau education. Fitch's new book on "The Arnolds" is worthy of his former fame and has received the most diligent care and study in its preparation.

Whether on such a flying trip you get much or little from a man depends on how you approach him. If you have read any of his writings, you have the key to his heart. Nothing perhaps pleases a man more than to be sought out by one of his unknown readers and find that his thoughts have taken root and awakened interest. I have never found any one unwilling to talk about bis published writings, their prospective new editions, and their circulation in America. It makes a great difference also whether you know anything of the man's work and line of interest, and whether you have done any study along that line yourself. Professors are generally pleased to discuss their ideas with intelligent and interested fellow-workers.

Prof. Sully has a grand opportunity if be will rise to the occasion. The child study people in England are looking to him for leadership, and there is no one in whom the teachers seem to have more confidence. He has it in his hands to develop the subject as he thinks best, but he has, unfortunately, been prevented by ill-bealth from taking a prominent part of late in the British Society for Child Study. It is high time that the development of sagacious and fruitful lines of investigation was lifting the work from the low plane of scrappy, rambling anecdotes. Such leadership requires boldness and insight. Prof, Geddes, of Edinburgh, has the qualifications, and if he were to throw his whole interest for a few years in that direction Great Britain would soon be doing as much as the United States; for the interest is present but a leader is as yet lacking.

'The Teachers' Guild in Gower Street, London, is a center for information about education. Amongst the interesting things in the library and pedagogic museum is a recently published portrait of Pestalozzi, discovered by $\mathrm{Mr}$. Russel on a trip through Switzerland. It seems to be a pencil sketch from life, with a great deal more life and truth in it than any of the older pictures.

The library of the Education Department formerly in the South Kensington, has moved into new quarters in one of the side streets off from Whitehall. The department of Special Inquiries and Reports is organized under Mr. Sadler and Mr. Morant on the model of our own Bureau of Education. They have begun the publication of these reports, the first volume appearing about a year ago, and the second volume being now due.

Interest in England at present centers in the organization of Secondary Education. Shall it, like elementary education, be centralized? If so, what shall be the constitution of the new central authority? Shall it be professional or political?

Dr. Warner is the champion of the study of the child "as a natural object by the laboratory method." His new edition of "How to stury children" is intended to be put in to the hands of teachers and parents. He has in MS., awaiting publication, another book on "Natural His- 
tory and Child Study," a manual for teachers in training. Furthermore he has in contemplation a philosophical work in two volumes to cover the whole ground of child study and unify all that is known about children. He expected to come to this country in the autumn to lecture and examine children and report on them.

James Ward was an early champion of the new psychology when fresh from Leipzig in 1876, and urged Cambridge to found a laboratory. But Cambridge laughed at him, and is only now beginning to take it up in earnest. Meanwhile Ward has drifted into metaphysics and is now deeply immersed in the theory of knowledge and does not keep up with the work elsewhere in psychology. Two of his pupils are rising into prominence-Mr. Stout, now at work on new genetic psychology, and W. E. Johnson, who is turning his attention to education.

Newntuam College has a daintily arranged, well-lighted, new library buildiug just completed, the gift of the Rev. Mr. Thompson.

Ebenezer Cooke, the author of the Alternative Syllabus in Drawing in the English Code, is a very interesting man. Rustic in appearance, with no highereducation, although a pupil of Ruskin, a plain, homely man, by himself he is working out his subject by observing children without concerning himself much with what is being dowe in other countries. All of the brush-work ideas advocated by Mrs. Rowland Hill in England, and by Mrs. Ella Goodwin Hunt in this country, are taken from Cooke without any acknowledgment. Cooke caught the idea from observing Jack I- playing with a brush, accidentally making an elliptical "blob," and then adding ears, tail and legs to make a mouse. The boy was so delighted with his discovery that he covered the paper with "blob" mice, and Cooke was equally delighted with his dis. covery, and incorporated it as the corner stone of his course in brushwork. Cooke believes in drawing from memory and imagination first before drawing from the object, thus emptying out one's misconceptions in order to get ready for learning. He is fond of quoting from Pestalozzi: "All true educative instruction must be drawn out of the child, and be germinated within it."

Prof. Patrick Geddes, of Edinburgh, is one of the most gevial, origiual, and fascinating men I met anywhere. He is in the prime of life, forty-four years old; has had a broad training in biology, working with Darwin and Huxley, and studying in England and on the continent; has turned to sociology in his spare time, and brought into it the biologic standpoint. For three mouths be is protessor of botany at Dundee, but for the rest of the year he resides in Edinburgh or travels. His sociologic work is extremely interesting and unique. For a while he lived with his wife in a one-room flat in the slum district of old Ediuburgh. There he learned to know the needs of the por $r$ and their privations, as well as the remedies and the possibilities for the rejuvenation of the Old Town. Eleven years ago he began University Hall, which has grown to embrace Ramsay Lodge, Riddle's Court, Blackie House, St. Giles House, and several others, acconmodating more than two hundred souls. Besides this he has renovated or built eighty-five attisans' dwellings, and the Old Town is fast changing into one of the most respectable sections of the city. Property has greatly appreciated in value, and Geddes has now turned the enterprise over to a stock company called The Town aud Gown Association, Limited. His idea is that higher education ought to train captains of industry who can lead the material forces into productive channels. The germ idea of University Hall is an organization of higher education, "to flower as many species of genius as possible," retainiog in mutually helpful association young artists, lawyers, phy sicians, accountants, teachers, historians, architects, engineers, etc. For, they all contribute in their respective spheres that in which they 
are experts. These people ought to be fellows or docents in the University of Edinburgh. They would contribute strength and the University would extend its influence in their lives beyond the mere lectures and examinations. This is what Geddes does in his "University," which is a self-governing republic of higher education. University Hall is chiefly scientific and literary; the new Observatory, the new Asylum, the geographical society and Museum of antiquities furnish new centers of scientific and potential collegiate development.

The tutorial assistance and higher studies immediately connected with Geddes's work are centered in the "Outlook Tower," the home of the Edinburgh Summer Meeting. Here are grouped: (a) geography, history, and social science with the co-operation of British and foreign geographers; (b) Scottish and Edinburgh history and Celtic studies; (c) Educational Museum; (d) Old Edinburgh School of Art, adapting old Scottish and Celtic designs to modern industries, decorating the students' halls, and preparing plans for a national mourment in the form of a frieze representiug a Procession of the Historical Personages of Scotland from the year 1000 to 1745 ; (e) the Publishing House of Patrick Geddes and Colleagues.

The false analysis of culture elements is destructive and vicious, like the analysis of foods into $\mathrm{C}, \mathrm{S}, \mathrm{Ph}$, etc. or into carbo-hydrates and the like. These are not foods, but the symbols of hades and death. Much of so-called biology is really necrology, for it is the study of death. The specialists in science are at the ash-heap of culture-the dead past. One rag picker finds old glass and china-that is the archæologist; another rakes up some fish or chicken bones or some feathers-that is the anatomist a la Prof. Huxley; another finds some stale flowers or dried leaves-the botanist; another some halfburned coal or slate-the geologist; charcoal and some sulphur are picked up by the chemist; letters and scribbled MSS. are raked out by the historian; and the antiquarian finds some old clothes, tin cans or bits of furniture. On the other hand, how different is real culture, not analytic but synthetic, not of death but of life. Give the children food instead of charcoal or carbo-hydrates. Vivendo discimus. Education arises out of life. Pupils must be fitted for the activities of life by actually sharing them; $e, g$., school accounts, book-keeping, decoretion of school building and school grounds, etc. Cecil Reddie's school at Abbotsholme, England, is working out its salvation inspired by these ideals. The individual and competitive spur to study becomes more than replaced by the co-operative and social one. Education is not merely by and for the sake of thought, but in a still higher degree by and for the sake of action; hence each course of acientific study is not merely related to those dealing with the other sciences, but in even more immediate degree to the corresponding arts of life. In the school of the future, as in the old churches of the Middle Ages, the books will be few but the pictures well-nigh infinite.

How shall we reach the faller perfection of the human hive? The proper relation of man to woman is best expressed in chivalry-the provisional religion of Western Feudalism. The boy's sword and the girl's doll furnish the starting point for the educator. Let the boy have his fling with war and fighting. Better there than afterward on Kaiser's throne or in the senate chamber. Every age of chivalry follows a period of decadence. The evolutionist education aims at the remoralization of the sexes. Its ideal is "women strengthened and trained by men, whom they have trained and strengthened."

The spirit of Geddes's ideas on education is best obtaiued by reading "The Evergreen, a Northern Seasonal" (Patrick Geddes and Colleagnes, Edínburgh.)

Herman T. LUKENS. 